\title{
A novel perspective in total knee arthroplasty
}

Citation for published version (APA):

Schotanus, M. G. M. (2018). A novel perspective in total knee arthroplasty: the patient specific instrumentation. [Doctoral Thesis, Maastricht University]. Maastricht University. https://doi.org/10.26481/dis.20181116ms

Document status and date:

Published: 01/01/2018

DOI:

10.26481/dis.20181116ms

Document Version:

Publisher's PDF, also known as Version of record

\section{Please check the document version of this publication:}

- A submitted manuscript is the version of the article upon submission and before peer-review. There can be important differences between the submitted version and the official published version of record.

People interested in the research are advised to contact the author for the final version of the publication, or visit the DOI to the publisher's website.

- The final author version and the galley proof are versions of the publication after peer review.

- The final published version features the final layout of the paper including the volume, issue and page numbers.

Link to publication

\footnotetext{
General rights rights.

- You may freely distribute the URL identifying the publication in the public portal. please follow below link for the End User Agreement:

www.umlib.nl/taverne-license

Take down policy

If you believe that this document breaches copyright please contact us at:

repository@maastrichtuniversity.nl

providing details and we will investigate your claim.
}

Copyright and moral rights for the publications made accessible in the public portal are retained by the authors and/or other copyright owners and it is a condition of accessing publications that users recognise and abide by the legal requirements associated with these

- Users may download and print one copy of any publication from the public portal for the purpose of private study or research.

- You may not further distribute the material or use it for any profit-making activity or commercial gain

If the publication is distributed under the terms of Article $25 \mathrm{fa}$ of the Dutch Copyright Act, indicated by the "Taverne" license above, 


\section{Chapter 11}

Summary

Nederlandse Samenvatting 


\section{Summary}

In this thesis, the potential of patient specific instruments (PSI) as an alignment tool in total knee arthroplasty (TKA) is explored.

In Chapter 1, as an introduction to this thesis, both the epidemiology and evolutionairy development of alignment tools for TKA are discussed. Given that the number of patients with osteoarthritis $(\mathrm{OA})$ in the western countries will increase due to the aging population and an increasing number of overweight people, there is need for optimization of the treatment pathway of OA. Long-term management of OA includes a wide variety of treatment strategies (e.g. weight management, medication and physical therapy). TKA is a last resort treatment for most patients with end-stage OA of the knee joint. One of the most important factors that affect the survival of the knee implant, is the alignment of the femoral and tibial components. For appropriate alignment of the TKA components several methods have been introduced. PSI is a relativelym recently introduced technique and the aim of this thesis is to study aspects of the clinical introduction and development of PSI for TKA, accuracy of the technique and future perspectives/alternative clinical applications of PSI.

The answers to the research questions, as formulated in Chapter 1, are subdivided into three sections as provided by the studies presented in this thesis. The main results are summarized and highlighted in these 3 main sections.

In the first section, the radiographical, the intra- and postoperative, and the clinical and midterm results of PSI for TKA are discussed.

In Chapter 2, the radiographical results of TKA with use of PSI from different manufacturers were compared with the results obtained with conventional instrumented TKA in a prospective non-randimized study. This single surgeon experience showed that, compared to conventional instruments, the proportions of outliers was in favour of PSI, without differences regarding the outliers between the individual PSI systems. We concluced that these high volume single surgeon results suggest that PSI are ready for daily use in TKA surgery.

PSI comes with a planning tool for which suggested planning settings should be approved by the operating surgeon. If not, the guides will be manufactured based on the templates calculated by a technician. Chapter 3 studied if the preoperative digital planning can accurately predict the component sizes as used intraoperatively. The preoperatively predicted femoral and tibial component size, approved by the operating surgeon, resulted in a more accurate prediction of the actual size of the femoral and tibial components used during surgery, as compared to the planning settings made by a technician. We concluded therefore, that in order to minimize intraoperative implant size error, the planning made by a technician should 
always be validated and approved by the operating surgeon, even more so because he bears the ultimate responsibility regarding the operation. Furthermore, this study showed that potential differences in component sizes could not be explained by the use of different imaging techniques, i.e. MRI- vs. CT-based templates. Both MRI- and CT-based PSI's showed comparable percentages of correctly predicted intraoperative implant sizes.

Published long-term clinical results on PSI are scarce since they have relatively recently been released. Chapter 4 provides the analysis of the longevity of the TKA implant and the clinical results of 180 patients who have been followed-up for 5-years in a multicentre RCT. At mid-term follow-up, there were no significant differences in the survival between PSI and conventional aligned TKAs, although slightly more implants were revised in the conventionally aligned TKA group. The clinical outcomes between PSI and conventionally aligned TKAs were comparable. We concluded this Chapter by stating that the literature on the mid- and long-term clinical follow-up is still scarce. Clinical results and revision rates of PSI derived from RCT's together with cost-effectiveness studies should demonstrate whether PSI still has the potential of becoming the golden standard for placing an elective TKA.

Section two deals with the differences between CT- and MRI-based PSI for TKA.

Chapter 2 described that the radiological results of TKA were comparable between the PSI from different manufacturers. However, the method of image acquisition and preoperative planning is not standardized among PSI manufacturers. The individual studies on this topic yielded different results. The comparison between MRI- and CT-based PSI for TKA using prosthetic components from one manufacturer was described in Chapter 5. This RCT was designed to study the radiographic accuracy of both scanning modalities. Only the number of outliers for the posterior slope of the tibial component showed a significant difference with more outliers in the CT-group than in the MRI-group.

The results described in Chapter $\mathbf{5}$ are in line with the results found in the systematic review and meta-analysis presented in Chapter 6. In this Chapter, evidence was provided that when performing TKA with PSI, a preoperative MRI is favourable for the production of PSI, resulting in a significantly lower proportion of outliers for the femoral component, as measured on lateral radiographs. The results of this study demonstrate that MRI should be the imaging modality of choice when performing TKA surgery with PSI.

The third section explores the potential of PSI as a reliable tool in patients with post-traumatic knee osteoarthritis and if PSI is a reliable tool for unicompartmental knee arthroplasty (UKA)to-TKA revision surgery. 
Chapter 7 describes that detailed preoperative planning is appropriate in the case of retained metal hardware. The preoperative planning is usefull to preplan the alignment and evaluate the post-operative correction as well as to check whether the implant interferes with the retained metal hardware. In most cases there was no need to remove the retained metal hardware as predicted with the PSI planning. With adequate preoperative planning, we know in advance how to cope with the retained metal hardware near the knee joint, resulting in an acceptable component alignment and improved clinical outcomes. CT-based PSI can be a valuable alternative in these cases.

The flexion/extension of the femoral component, however showed undesirable outcome in our study. Based on our experience, these disappointing results could be that the CT-guides were not adequately positioned. With the four-point fixation, tibia guides refer to the anterior bone but does not make any contact with the cartilaginous surface of the medial and lateral tibia plateau. With a standard $5 \mathrm{~mm}$ off set to remain distance to the cartilage, they do not rest snuggly on the remaining cartilage.

PSI were initially developed for the alignment of both TKA and UKA. Revision surgery of failed UKA is considered as a technically demanding procedure due to possible bone lose, the potential need for augmentations, use of long-stem prosthesis and requires careful preoperative planning. As found in Chapter 3 and Chapter 7, accurate pre-operative planning can reduce unexpected perioperative problems especialy in these complicated cases of failed UKA. Chapter 8 introduced a unique new concept regarding PSI: UKA-to-TKA revision surgery. The most important finding was that PSI for UKA-to-TKA revision surgery resulted in a limited number of rotational outliers, especially for the femoral component of the TKA. The tibial guide seems more susceptible to errors, resulting in a substantial percentage of outliers. PSI as a "new" tool for UKA-to-TKA revision surgery appears to be an accurate tool for the alignment of the TKA femur component, but less so for the tibial component.

Based on the work presented in this thesis, Chapter 9 gives a general discussion of the current and future development of PSI for the treatment of knee OA. Clinical results from long-term randomized studies and cost-effectiveness studies should demonstrate whether PSI become the new golden standard for placing an elective TKA. PSI appears to be emerging as the dominant design, despite the widespread use of an unproven long-term design.

\section{Closing remarks and future investigation}

Past decenia, three dimensional printing (3D) is changing the Health Care. Nevertheless, the major problem of these 3D-printed medical solutions are the high costs. New medical technologies are expensive when they enter the market, they become cheaper over time. This applies to the cost of 3D-printe PSI as well and the technology becomes more accessible, within a reasonable price. 
Recommendations for future research:

- Furthur develop PSI for revision arthroplasty of failed UKA and make this appplication accessible for every (experienced) orthopedic surgeon.

- Furthur development of PSI based on x-ray planning instead of MRI or CT-scan.

- Study of the exact cost-effectivness of PSI for TKA.

- Further exploration of the Knee in Box philosophy.

Recommendations for the daily orthopedic practice:

- The Dutch Arthroplasty Register (LROI) contains information on orthopaedic prosthesis procedures in the Netherlands. The registration of TKA and UKA implants does not include the method of alignment. For this, I would recommend to add this to the registration, including the type of scan modality which is used to produce the PSI.

- New technologies, including PSI and robotic surgery, should be added to the training curriculum to become orthopaedic surgeon.

- Finaly, if you use PSI, spend time on the preoperative planning! 


\section{Nederlandse Samenvatting}

In deze thesis wordt het potentieel van patient-specifiek instrumentarium (PSI) nader beschouwd.

In Hoofdstuk 1 wordt, bij wijze van introductie tot dit proefschrift, zowel de epidemiologie als de evolutionaire ontwikkeling van de totale knie arthroplastiek (TKA) geschetst. Tevens wordt bediscussieerd dat het aantal patiënten met artrose in de westerse landen zal toenemen als gevolg van de vergrijzing van de bevolking en door een toename van het aantal mensen met overgewicht. In dat kader is optimalisatie van het behandelalgoritme van artrose van belang. Behandeling van artrose op de lange termijn omvat een breed scala aan behandelingsstrategieën (bijvoorbeeld gewichtsbeheersing, medicijnen en fysiotherapie). Voor de meeste patiënten met een eindstadium van artrose van het kniegewricht is de TKA de meest geindiceerde behandeling. Een van de belangrijkste factoren die de overleving van het implantaat beïnvloeden, is de uitlijning van de femur- en de tibia-component. Voor een juiste uitlijning van de TKAcomponenten zijn verschillende methoden geïntroduceerd. PSI is een relatief nieuwe methode om een TKA uit te lijnen en het doel van dit proefschrift is dan ook om aspecten van de klinische introdcuatie en ontwikkeling van PSI voor TKA te besturderen. Bovendien zal de accuratesse van de techniek en het toekomstperspectief/alternieve klinische applicaties aan de orde komen.

De antwoorden op de onderzoeksvragen, zoals geformuleerd in Hoofdstuk 1, zijn onderverdeeld in drie secties. De belangrijkste resultaten zijn samengevat en gemarkeerd in deze 3 secties.

De eerste sectie bediscussieert de radiografische, de intra- en postoperatieve en de 5 jaars klinische resultaten van PSI voor TKA.

In Hoofdstuk 2 werden de radiografische resultaten van TKA met gebruik van PSI van verschillende fabrikanten vergeleken met de conventionele geïnstrumenteerde TKA in een prospectieve niet-gerandomiseerde studie. De resultaten toonde aan dat de proporties van uitschieters, in vergelijking met conventioneel instrumentarium, in het voordeel van PSI waren, zonder verschillen met betrekking tot de uitschieters tussen de afzonderlijke PSI-systemen. We concludeerden dat deze resultaten van een hoog volume chirurg suggereren dat PSI klaar is voor dagelijks gebruik bij TKA chirurgie.

PSI wordt geleverd met een computerprogramma, waarbij de voorgestelde planning moet worden goedgekeurd door de opererende chirurg. Als dat niet het geval is, wordt het PSI vervaardigd op basis van de planning die door een technicus is gemaakt. Hoofdstuk 3 bestudeert of de pre-operatieve digitale planning de implantaat maten nauwkeurig kan voorspellen die intraoperatief worden gebruikt. De preoperatief voorspelde femur en tibia component maten, 
goedgekeurd door de opererende chirurg, resulteert in een meer accurate voorspelling van de werkelijk geplaatste maten peroperatief, in vergelijking met de planningsinstellingen die door een technicus zijn gemaakt. We concludeerden derhalve dat, om fouten in de intraoperatieve implantaat maatvoering tot een minimum te beperken, de planning altijd moet worden gevalideerd en goedgekeurd door de opererende chirurg, vooral ook omdat laatstgenoemde de eindverantwoordelijkheid draagt voor de operatie. Bovendien konden potentiële verschillen in de maatvoering van de TKA componenten niet verklaard worden door de verschillende beeldvormingstechnieken, d.w.z. op MRI danwel op CT gebaseerde PSI. Zowel het op MRI- als het op CT-gebaseerde PSI vertoont vergelijkbare percentages van correct voorspelde intraoperatieve implantaatmaten.

Gepubliceerde langetermijn klinische resultaten van PSI zijn schaars aangezien ze relatief recent op de markt zijn verschenen. Hoofdstuk 4 geeft een beschrijving van de levensduur van het TKA-implantaat en de klinische resultaten van 180 gerandomiseerde patiënten, die nu 5 jaar lang in een multicenter RCT gevolgd zijn. Op middellange termijn waren er geen significante verschillen in de overleving tussen de middels PSI en de middels conventionele uitgelijnde TKA's. Echter, iets meer implantaten werden gereviseerd in de conventionele TKA-groep. De klinische uitkomsten tussen PSI en conventioneel uitgelijnde TKA's waren vergelijkbaar. De klinische resultaten en de revisie percentages van PSI uit RCT's, samen met kosteneffectiviteitsstudies moeten aantonen of PSI potentie heeft om de gouden standaard te worden voor het plaatsen van een TKA.

Sectie twee handelt over de verschillen tussen op MRI en op CT gebaseerde PSI voor TKA.

Hoofdstuk 2 beschreef dat de radiologische resultaten van TKA vergelijkbaar waren tussen het PSI van verschillende fabrikanten. Echter, de methode van beeldacquisitie en pre-operatieve planning is niet gestandaardiseerd tussen de PSI-fabrikanten. De individuele onderzoeken over dit onderwerp leverden verschillende resultaten op. De vergelijking tussen de op MRI- en CT-gebaseerd PSI voor TKA van één fabrikant werd beschreven in Hoofdstuk 5. Deze RCT werd opgezet om de radiografische nauwkeurigheid van beide scanmodaliteiten (MRI en CT) voor de productie van PSI voor de uitlijning van de TKA te onderzoeken. Alleen het aantal uitschieters voor de posterieure hellingshoek van de tibia component toonde een verschil, met significant meer uitschieters in de CT-groep vergeleken met de MRI-groep.

De resultaten beschreven in Hoofdstuk 5 komen overeen met de resultaten uit de systematische review en meta-analyse, gepresenteerd in Hoofdstuk 6. In dit Hoofdstuk werd bewijs geleverd dat waneer een TKA procedure middels op MRI gebaseerd PSI werd uitgevoerd, dit resulteerde in een significant lager aantal uitschieters voor het femorale component, zoals gemeten op 
laterale röntgenfoto's (flexie-extensie). De resultaten van deze studie tonen aan dat MRI de beeldvormingsmodaliteit van keuze moet zijn bij het uitvoeren van TKA-chirurgie met PSI.

De derde sectie exploreert het potentieel van PSI bij patienten met elektronische hulpmiddelen zoals een pacemaker, patienten met gewrichtsmisvormingen van het kniegewricht (posttraumatisch), patienten met metaal rondom het kniegewricht van eerdere operaties en/of patienten met een halve knie artroplastiek (HKA). Bij deze patiënten is een MRI niet mogelijk. Derhalve wordt in in dit derde deel besproken of PSI een betrouwbare uitlijnmethode is bij patiënten met posttraumatische artrose in de knie en of PSI een betrouwbaar instrument is voor HKAnaar-TKA revisiechirurgie.

Hoofdstuk 7 beschrijft dat gedetailleerde pre-operatieve planning geschikt is in het geval van posttraumatische knie artrose. De pre-operatieve planning is nuttig om de uitlijning vooraf te bepalen en zo de postoperatieve correctie te evalueren. Tevens biedt het de mogelijkheid om te controleren of het implantaat interfereert met de aanwezige metalen onderdelen van eerdere operaties. In de meeste gevallen was het niet nodig om de metalen onderdelen te verwijderen zoals voorspeld met de PSI planning. Met adequate pre-operatieve planning weten we van tevoren hoe om te gaan met de metalen onderdelen bij het kniegewricht, wat resulteert in een acceptabele uitlijning van de componenten en verbeterde klinische uitkomsten. De op CT gebaseerde PSI kan in deze gevallen een goed alternatief zijn.

De flexie/extensie uitlijning van het femorale component vertoonde echter een ongewenst resultaat in onze studie. Op basis van onze ervaring zouden deze teleurstellende resultaten het gevolg kunnen zijn van het feit dat het op CT gebaseerde PSI niet adequaat gepositioneerd kon worden. Met de vierpuntsbevestiging refeereert de tibiamal aan de voorzijde van de tibia, maar makt geen enkel contact met het kraakbeenachtige oppervlak van het mediale en laterale tibiaplateau. Er is een standaard ruimte van $5 \mathrm{~mm}$ tussen het PSI en het overgebleven kraakbeen en de mal rust daarom niet stabiel op de proximale tibia.

PSI werd oorspronkelijk ontwikkeld voor de uitlijning van zowel de TKA als de HKA. Revisiechirurgie van een HKA wordt beschouwd als een technisch veeleisende procedure vanwege mogelijk botverlies, de potentiële behoefte voor augmentaties, gebruik van lange steel prothese en vereist zorgvuldige pre-operatieve planning. Zoals te vinden is in Hoofdstuk 3 en Hoofdstuk 7 , kan accurate pre-operatieve planning onverwachte perioperatieve problemen verminderen, met name in deze gecompliceerde gevallen van een gefaalde HKA. Hoofdstuk 8 introduceerde een uniek nieuw concept met betrekking tot PSI, HKA-naar-TKA-revisiechirurgie. De belangrijkste bevindingen waren dat PSI voor HKA-naar-TKA-revisiechirurgie resulteerde in een beperkt aantal rotatie-uitschieters, in het bijzonder het femorale component van de TKA. De tibia mal lijkt vatbaarder voor fouten, wat resulteert in een aanzienlijk percentage uitschieters. PSI als een nieuw hulpmiddel voor HKA-naar-TKA-revisiechirurgie blijkt een nauwkeurig 
hulpmiddel te zijn voor de uitlijning van het TKA-femurcomponent, maar in mindere mate voor de tibia component.

Gebaseerd op het werk gepresenteerd in dit proefschrift, geeft Hoofdstuk 9 een algemene discussie over de huidige en toekomstige ontwikkeling van PSI voor de behandeling van knieartrose. Klinische resultaten van gerandomiseerde langetermijnstudies en kosteneffectiviteitsstudies moeten aantonen of PSI de nieuwe gouden standaard kan worden voor het plaatsen van een TKA. PSI lijkt zich te onwikkelen tot een dominant ontwerp, ondanks het wijdverbreide gebruik van een onbewezen langetermijnontwerp.

\section{Slotopmerkingen en toekomstig onderzoek}

De afgelopen decennia, verandert drie dimensionaal (3D) printen de gezondheidszorg. Het grote probleem van deze 3D geprinte medische toepassingen zijn echter de hoge kosten. Nieuwe medische technologieën zijn duur wanneer ze op de markt komen, ze worden goedkoper in de loop van de tijd. De kosten van 3D-printen nemen af en de technologie wordt beter toegankelijk, tegen een redelijke prijs.

Aanbevelingen voor toekomstig onderzoek:

- Verdere onwikkelingen van PSI voor revisieartroplastiek bij een falende HKA. Tevens dit toegankelijk maken voor elke (ervaren) orthopedisch chirurg.

- Verdere onwikkelingen van PSI op basis van röntgenplanning in plaats van MRI of CT.

- Verdere bestudering van de exacte kosteneffectiviteit van PSI voor TKA.

- Verder exploreren van de 'Knie in een doos' filosifie.

Aanbevelingen voor de dagelijkse orthopedische praktijk:

- De Landelijke Registratie Orthopedische Implantaten (LROI) bevat informatie over de orthopedische prothese-ingrepen in Nederland. De registratie van implantaten van TKA en UKA bevat niet de uiitlijnmethode. Op basis van dit proefschrift wil ik aanbevelen dit aan de registratie toe te voegen, inclusief het type scanmodaliteit dat wordt gebruikt om de PSI te produceren.

- Nieuwe technologieën, waaronder PSI en robotchirurgie, moeten worden toegevoegd aan het opleidingsprogramma om orthopedisch chirurg te worden.

- Tot slot, als u PSI gebruikt, besteedt dan genoeg tijd aan de pre-operatieve planning! 